Editoriais / Editorials

\section{Max Weber e o Gespública Max Weber and Gespublic}

\section{João Carlos P. Saraiva}

Max Weber, filosofo alemão, foi um dos mais importantes teóricos da burocracia, descrevendo as suas características, sistematizando-a e enaltecendo-a como fator de transformação de uma sociedade.

Alguns dos conceitos básicos da burocracia de Weber é exatamente aquele que é constantemente desprezado, o da meritocracia, ou seja, a ascensão de um burocrata na instituição se faz determinada pelos seus méritos. Weber também fala do comprometimento do burocrata com a instituição que lhe emprega, mantendo uma relação de confiança mútua.

A onda mundial da qualidade nas empresas privadas estimulou os governos a acompanhar um processo que era exigido pelo consumidor dos produtos e serviços oferecidos pelas empresas.

Começaram a ser implementados programas de qualidade nos serviços públicos, modificando paradigmas enraizados, o principal deles estabelecido que o serviço público era ruim pelo simples fato de ser serviço público e ser operacionalizado por burocratas.

No Brasil, os primeiros passos foram dados com a criação, em 1990, do Subprograma de Qualidade e Produtividade na Administração Pública, que focava a gestão de processos, na tentativa de racionalizar e padronizar os processos envolvidos no atendimento ao cidadão. Foi um processo que ficou restrito ao plano federal, com pequenas repercussões nos estados.

Em 1996, o Programa de Qualidade e Participação na Administração Pública sinalizou a evolução do processo iniciado seis anos atrás, mirando agora, além da gestão, os resultados decorrentes dos processos.

Em 2000, o PQSP (Programa de Qualidade no Serviço Público) resumiu e codificou todos os processos focados na qualidade do atendimento ao usuário. Nessa década, alguns hemocentros iniciaram seus programas de qualidade, com diferentes metodologias, ainda sem a interação com os programas federais. Alguns hemocentros, mais tarde, aderiram ao programa federal e ao seu sistema de pontuação, atingindo premiações de ouro, prata e bronze (Hemorio, Hemominas e Hemopa).

O Decreto No 5378, de 23 de fevereiro de 2005, instituiu o Programa Nacional de Gestão Pública (Gespública), nascido da fusão de dois programas, o PQSP e o Programa Nacional de Desburocratização, com o propósito de potencializar as ações desenvolvidas e fazer com que os resultados sejam mais visíveis. De 1990 até 2005, mais de três mil organizações nacionais, públicas e privadas aplicaram técnicas de melhoria de gestão, contribuindo para que o serviço de atendimento às necessidades do público tivesse um salto considerável de qualidade.

O Gespública é liderado pelo Ministério do Planejamento, possuindo um Comitê Gestor, constituído por representantes do Governo Federal e de organizações públicas reconhecidas no trabalho de qualidade na gestão pública. Possui três características: 1) É público; 2) Tem o resultado como foco principal; 3) É federativo, isto é, engloba todos os níveis da administração publica: federal, estadual e municipal.

Como dito anteriormente, a burocracia é apontada como o principal entrave à prestação de serviços públicos de qualidade. Entretanto, o burocrata, na acepção weberiana do termo, é o que menos influencia nos destinos das instituições.

Temerariamente, tem-se observado nos últimos anos o aparelhamento político-partidário do Estado, nos seus mais diversos níveis, a meritocracia preconizada pelos teóricos da burocracia, e substituída pela "partidariocracia", que não traz consigo o comprometimento e a continuidade dos programas de governo.

A Fundação Hemominas tem uma tradição de qualidade no seu serviço e, atualmente, encontra-se dentro de um contexto estadual de choque de gestão, ao qual não foi difícil se adaptar.

Chama atenção a implantação do Gespública em unidades do interior do estado, com resultados próximos aos obtidos no hemocentro coordenador, superando uma das maiores dificuldades dos hemocentros, a interiorização de suas atividades.

Constitui-se inegavelmente em exemplo de superação e de determinação administrativa de um hemocentro que, sob a direção de Ana Barbara Proietti, mantém a linha política e administrativa de seus antigos dirigentes, como Laércio de Melo e Ângela Givisiez.

Avaliação: $\mathrm{O}$ tema abordado foi sugerido e avaliado pelo editor.

Recebido: $23 / 03 / 2008$

Aceito: $26 / 03 / 2008$

Diretor de Comunicação da Sociedade Brasileira de Hematologia e Hemoterapia.

Correspondência: João Carlos Pina Saraiva

Rua dos Caripunas, 3459

66063-040 - Belém-PA - Brasil

E-mail:saraiva@amazon.com.br 